\title{
Observations on the Reaction of Protoplasm to some Reagents.
}

\author{
BY \\ WILLIAM SEIFRIZ. \\ With four Figures in the Text.
}

$\mathrm{N}$ the following pages are given part of the results obtained in a series of
experiments on the reaction of protoplasm to some common reagents. The effect of ethyl alcohol and of the three glucosides, saponin, smilacin, and senegin, on the living protoplast are here recorded.

\section{Material AND REAGENTS.}

The leaves of Elodea served as material. All observations were made only on the superficial cells of the upper side of the leaf. The cells on the upper surface were found to differ somewhat from the upper cells in their sensitivity to certain of the reagents.

The reagents employed for treating the cells were ethyl alcohol, saponin, smilacin, and senegin. These reagents were all obtained from Merck (Darmstadt). The saponin (pur. albiss.) is extracted from the Levantine soaproot Gypsophila struthium. The smilacin comes from sarsaparilla roots, commercially known as radix sarsaparillae, and obtained from various species of Smilax. Senegin is extracted from the roots of Polygala senega.

The water used in making the solutions was spring water, the same in which the Elodea plants were kept growing in the laboratory; it is in Geneva, very pure.

\section{PART I.}

\section{THE REACTION OF PROTOPLASM TO ETHYL ALCOHOL.}

\section{Experimental Data.}

Lethal Effect of Alcohol. Overton, whose pioneer work on osmotic properties of the cell gave us the first information we have on the effect of many reagents on protoplasm, states that methyl and ethyl alcohol of 3 per 
cent. by weight are not harmful to the plant cell after a long time (18, p. 105). One would, therefore, expect no harm to result from a 3 per cent. solution of alcohol, and relatively little from a 10 per cent. solution, after no more than a few hours of treatment. Quite the contrary, however, is true. A so per cent. concentration of ethyl alcohol is sufficiently strong to kill, on an average, 60 per cent. of the cells in an Elodea leaf within half an hour, 80 per cent. of them within an hour, and 95 per cent. within two hours. A 3 per cent. concentration of alcohol will kill, on an average, more than half the number of cells in from four to six days. If the cells of the Elodea leaf are unusually sensitive to alcohol, a 2 per cent. concentration will kill 50 per cent. of them in less than two days.

An interesting fact in connexion with the toxicity of alcohol on protoplasm is the variability in sensitivity of cells both in the same leaf and in different
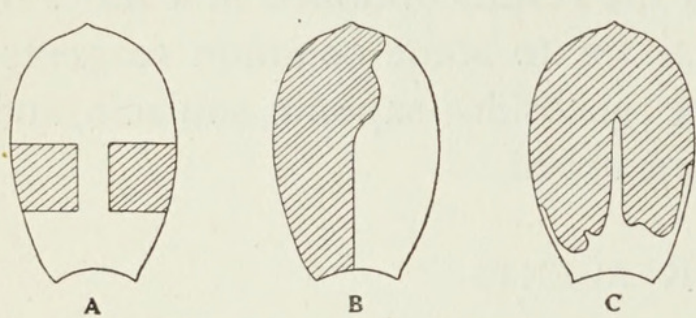

FIG. I. Diagrammatic sketches indicating those regions of an Elodea leaf which first succumb to the toxic effect of ethyl alcohol. A. The cells killed may, as result of brief treatment in ro per cent. alcobol, be situated in two blocks occupying corresponding positions on opposite sides of the midrib sharply delimited from the remaining leaf area of living cells. B. The dead cells, after longer treatment, may occupy the entire half of the leaf. C. The typical distribution of living and dead cells of a leaf treated for one hour in Io per cent. ethyl alcohol. The very basal cells are the last to succumb.

leaves. It was a common instance to find a dead cell, killed by the reagents, next to an actively streaming one, and to find certain cells which would withstand the poisonous effect for twenty-four hours while others in the same leaf succumbed in half an hour.

The dead cells are usually grouped in patches, suggesting a common physiological state before death in these regions. The less resistant cells may be grouped into two blocks situated in similar positions on each side of the leaf (A, Fig. 1); or the cells in one entire half of a leaf may be killed while those in the other half remain alive and apparently normal (B, Fig. I). In leaves treated in 10 per cent. alcohol, which kills quickly, there are definite regions which are in all cases more or less resistant to the alcohol. The few cells situated at the base of the leaf, extending a little way up each edge and still farther up the mid-rib, are the last to succumb to the toxic effect of io per cent. ethyl alcohol (C, Fig. I). So pronounced is this difference in resistance that, while all the other cells, i.e. 95 per cent. of the total, may sometimes, in a more sensitive leaf, be killed in half an hour in ro per cent. alcohol, it requires six hours or more of treatment to kill the two or three hundred cells situated in the base of the leaf. On the other hand, the alcohol-resistant basal cells are as sensitive as any in the leaf to some other reagents, e. $g$. to strontium chloride.

This variability in behaviour is not only true of different cells in a leaf, 
but also of different leaves on the same shoot, and of different shoots in one lot of plants, and again, of different lots collected at different times and in different localities.

What all the controlling factors are, it is impossible to say. One or two of them were, however, ascertained. Young and luxuriantly growing Elodea plants are less resistant to alcohol than are older plants. Also, the longer the time plants remain in culture in the laboratory the greater does their resistance to alcohol become. (The osmotic pressure of the cell is likewise increased.)

The variability in reaction of the different cells of the same leaf can only be attributed to different physiological states of the cells, the causes of which are as yet unknown.

This variability in behaviour of the cells of Elodea leaves made it necessary to make many observations in order to obtain a general average of behaviour. Only such grand averages, unless otherwise stated, are given in this paper. In most instances these averages are based on the observation of more than a hundred leaves, representing many thousands of cells, for each time of treatment in every concentration of the several reagents used.

The average length of time necessary to kill an Elodea protoplast with Io per cent. ( $\cdot \cdot 7 \mathrm{M})$ ethyl alcohol is about (slightly less than) half an hour: In the most resistant leaf found every cell withstood the harmful effect of ro per cent. alcohol for two hours, not a single dead cell being found. That the cells suffered to a considerable extent, which was not superficially noticeable, is inevitable. Such extreme resistance is, however, rare. In only one leaf in a hundred do all the cells survive the toxic effect of 10 per cent. alcohol for one hour. In contrast to these instances are those of two other leaves, in one of which 9.7 per cent. of the cells were killed in Io pẹr cent. alcohol in half an hour, and in the other, 99 per cent. were killed in one hour. ${ }^{1}$

The curve in Fig. 2 depicts the average rate at which a 10 per cent. solution of ethyl alcohol kills the cells of Elodea. The ordinates are minutes and hours of treatment in the alcohol. The abscissae are percentages of cells killed. It will be seen that in the average Elodea leaf no cells are

1 The criterion of death used was inability to plasmolyse with a ro per cent. solution of potassium nitrate. The average critical plasmolytic concentration, i. e. that concentration of plasmolysing salt which will, in a half-hour, plasmolyse about 5 o per cent. of the total number of cells in a leaf, is 3 per cent. $\mathrm{KNO}_{3}$; therefore it is reasonable to assume that a cell incapable of plasmolysis with Io per cent. $\mathrm{KNO}_{3}$ is dead. To prove the truth of this a 20 per cent. solution of potassium nitrate was applied after a ro per cent. solution, and no additional cells were plasmolysed. To further convince myself that these alcohol-treated cells which could not be plasmolysed with io per cent. $\mathrm{KNO}_{3}$, were dead, I observed whether or not cells treated in 10 per cent. alcohol for twenty minutes, half an hour, and one and a half hours would recover. There was no recovery after three days in water. Other indications of death are also usually present, such as an irregularly shrunken (coagulated) and discoloured protoplast. 
killed in Io per cent. ethyl alcohol within ten minutes, but in fifteen minutes several cells (O.I per cent.) die, and in twenty minutes $I$ per cent. are killed. The percentage of cells killed then increases with the length of time of treatment. After 95 per cent. are dead the curve rises very rapidly, due to the great resistance of the few basal cells. All cells, including the basal ones, succumb in 10 per cent. alcohol overnight.

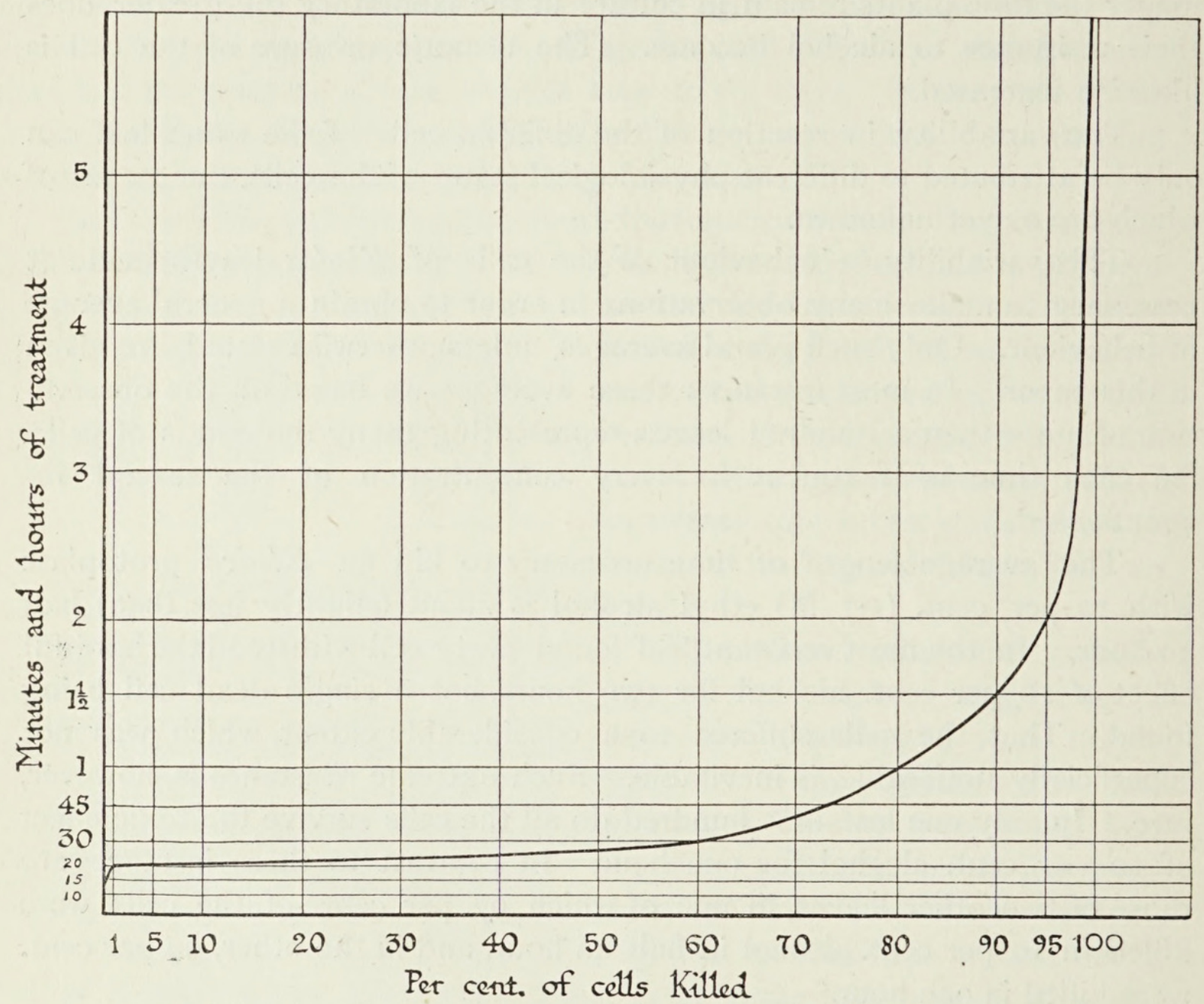

FIG. 2. The curve depicts the average rate at which Elodea leaf cells are killed in a solution of to per cent. ethyl alcohol. The ordinates are minutes and hours of treatment. The abscissae are percentages of cells killed. Thus, O.I per cent. of the cells of an Elodea leaf are, on the average, killed in Io per cent. alcohol within fifteen minutes; I per cent. are killed in twenty minutes; 60 per cent. in half an hour; 95 per cent. in two hours. The sudden rise of the curve is due to the great resistance of the few basal cells of the leaf, which usually require from six to twelve hours to kill in 10 per cent. alcohol. The curve is an ideal one based on many averages, the variations in resistance of different cells in a leaf, and of different leaves, being very great.

The story of the toxic effect of alcohol on Elodea leaves can be told in another way. The curve in Fig. 3 represents the rate at which different strengths of solutions of ethyl alcohol kill the cells. The time in which a solution of alcohol would kill half the number of cells was chosen as a data upon which to plot the curve. By examining the curve one can ascertain how long an average cell may remain in an alcoholic solution of a certain strength and stand an even chance of surviving. Thus, in 5 per cent. 
(0.9 M) ethyl alcohol half of the cells will be killed in forty hours, and half survive.

It must be remembered, however, that no cell probably escapes without considerable ill effect when the time of treatment is sufficient to kill 50 per cent. of them. For concentrations below 4 per cent. the curve can be regarded as only approximate, since in weak solutions the time required to

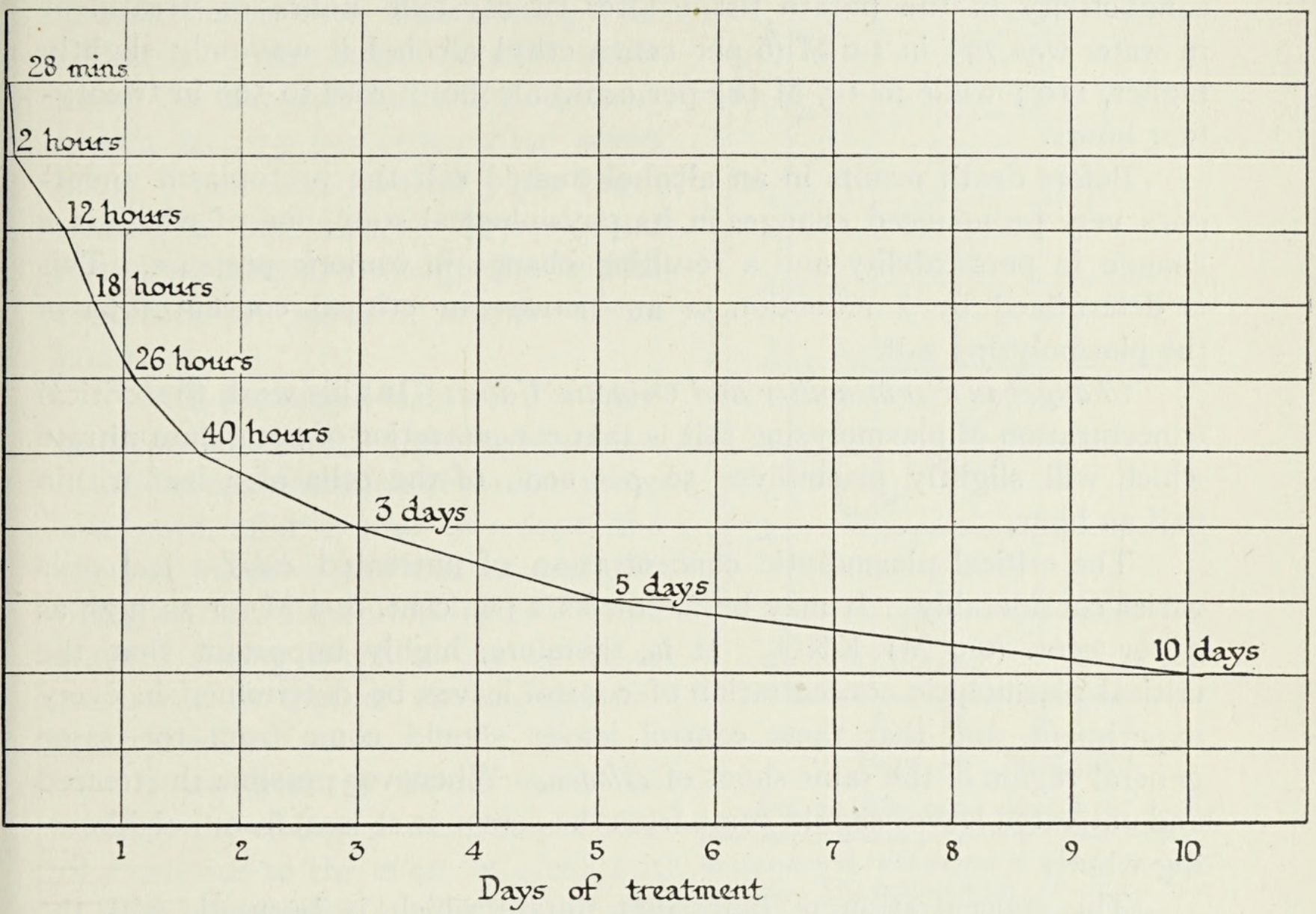

FIG. 3. The curve is based on the time required to kill half of the total number of cells on an Elodea leaf in solutions of ethyl alcohol of concentrations of I to Io per cent. The ordinates are percentages of alcohol in solution. The abscissae are days of treatment. The curve shows, for example, that a cell will stand an even chance of surviving after being twenty-eight minutes in 10 per cent. alcohol, eighteen hours in 7 per cent. alcohol, \&c.

kill varies greatly. Thus, in material subsequently worked upon in London ${ }^{1}$ all cells in an Elodea leaf, including the more resistant basal ones, were killed in a 2 per cent. (0.3 M) alcohol solution in two days. Furthermore, the cells may become much deteriorated in a few days apparently without actually dying,

From the curve it will be seen that a concentration of about 9 per cent.

${ }^{1}$ Some of the experiments here recorded were repeated on Elodea collected near London with the purpose of ascertaining if different specimens growing in different localities reacted differently to the reagents. These duplicate experiments were carried out in the Huxley Laboratory of the Department of Botany of the Imperial College of Science and Technology, London. The writer wishes to express to Professor V. H. Blackman his appreciation of the courteous and helpful treatment which was accorded him while working in the Huxley Laboratory. 
( 1 .6 M) is a critical point in the toxicity of ethyl alcohol on protoplasm. Above this concentration the protoplasm is killed in relatively few minutes. Below this concentration many hours are necessary to cause death. It is at about this concentration $(\mathrm{I} \cdot 5 \mathrm{M})$ that Stiles and Jørgensen $(22, \mathrm{p} .60)$ obtained a marked increase in the exosmosis of electrolytes from potato in solutions of ethyl alcohol. They found that the rise in electrical conductivity of the potato tissue after twenty-four hours of treatment in water was 79 ; in I.० M (6 per cent.) ethyl alcohol it was only slightly higher, 110 ; while in $1.5 \mathrm{M}\left(8 \frac{1}{2}\right.$ per cent.) alcohol it rose to 509 in twentyfour hours.

Before death results in an alcohol-treated cell the protoplasm undergoes very pronounced changes in its physiological state, one of which is a change in permeability and a resulting change in osmotic pressure. This is determined by a reduction or an increase in critical concentration of the plasmolysing salt.

Changes in Permeability and Osmotic Value. In this work the critical concentration of plasmolysing salt is that concentration of potassium nitrate which will slightly plasmolyse 50 per cent. of the cells of a leaf within half an hour.

The critical plasmolytic concentration of untreated Elodea leaf cells varies considerably. It may be as low as 2 per cent. $(0.3 \mathrm{M})$ or as high as 5 per cent. $(0.9 \mathrm{M}) \mathrm{KNO}_{3}$. It is, therefore, highly important that the critical plasmolytic concentration of control leaves be determined in every experiment, and that these control leaves should come from the same general region of the same shoot of Elodea. Whenever possible the treated and untreated leaves should come from the same, or at least from neighbouring whorls.

The concentration of potassium nitrate which is isosmotic with the contents of the average Elodea cell, i. e. the average critical plasmolytic concentration of untreated cells, is 3 per cent. $(0.5 \mathrm{M})$, and unless otherwise stated this value will be employed for comparison.

Cells placed for one quarter of an hour in Io per cent. ( $(1 \cdot 7 \mathrm{M})$ ethyl alcohol show little change in their osmotic values. After half an hour of treatment there is a noticeable reduction in the critical concentration of the plasmolysing salt-from 3 per cent. of the control leaves to 2.8 per cent. of the treated leaves. Prolonged treatment still further lowers the osmotic value of the alcohol-treated "cells. The critical plasmolytic concentration of cells which have remained in Io per cent. alcohol for three-quarters of an hour (and, of course, have remained alive) is 2.6 per cent. (the control still being 3 per cent.), and after one hour it is 2.5 per cent.

The reduction in osmotic value of cells treated in 10 per cent. alcohol cannot be so readily determined owing to the rapidity with which the cells are killed. With lower percentages of alcohol the gradual decrease in the 
osmotic pressure of the cell, as determined by the critical concentration of the plasmolysing salt, is very marked and readily followed.

In 8 per cent. $(\mathrm{I} \cdot 4 \mathrm{M})$ ethyl alcohol the decrease in critical plasmolytic concentration is noticeable after one hour of treatment, although the amount of reduction is then slight, being 0.25 per cent. After four hours of treatment the decrease in critical concentration is 0.75 per cent., after seven hours I per cent. (control 3 per cent., treated 2 per cent.). There is no further reduction, although the critical concentration remains low for some hours.

With prolonged treatment in ser cent. alcohol there is a gradual increase in critical concentration of plasmolysing salt, until, after one or two days, the osmotic value of the treated and still living cell has risen from the low value reached during the first few hours of treatment to that of the normal untreated cell.

If we wish to follow more accurately the change in osmotic pressure of a cell due to the effect of alcohol it is best done with a solution of still lower percentage. This has been done for 3 per cent. $(0.5 \mathrm{M})$ ethyl alcohol. The values are given in the form of a curve in Fig. 4. The abscissae are days of treatment. The ordinates are critical plasmolytic concentrations.

It will be noticed that there is no change in the critical concentration of salt (and therefore in the osmotic value of the cell) for eight hours. In eighteen hours the critical plasmolytic concen-

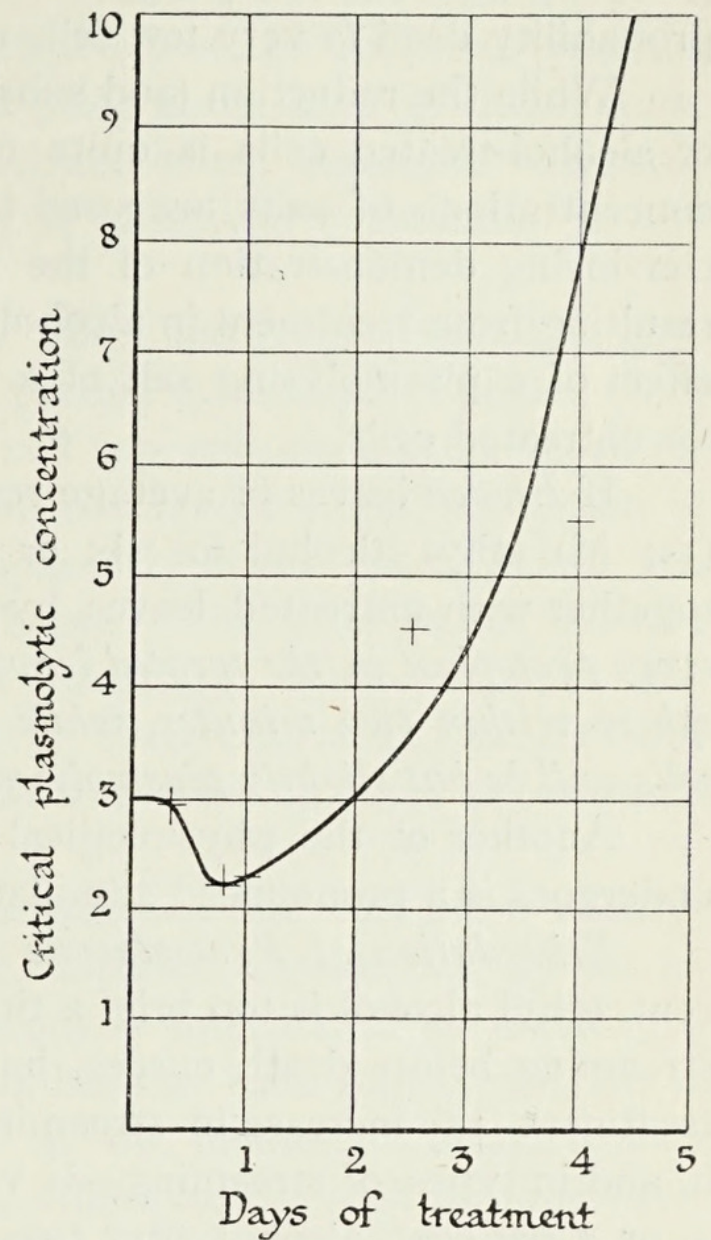

FIG. 4. The curve depicts the change in concentration of potassium nitrate necessary to plasmolyse cells treated in 3 per cent. ethyl alcohol. The ordinates are the critical plasmolytic concentrations, 3 per cent. being that of the untreated leaf. The abscissae are days of treatment. Eight hours' treatment in 3 per cent. ethyl alcohol are necessary before an appreciable reduction in critical concentration of potassium nitrate takes place. After eighteen hours' treatment the lowest critical plasmolytic concentration (2.2 per cent.) is reached. After two days' treatment the critical concentration has returned to the normal ( 3 per cent.). In two and a half days it has risen far above normal (to 4.5 per cent.), in four days to 5.5 per cent., and in five days to above 10 per cent. Since the osmotic pressure of the cell varies directly as the critical plasmolytic concentration, the curve indicates also the changes in osmotic value due to treatment in ethyl alcohol. tration has fallen to $2 \cdot 2$ per cent. (the normal being 3 per cent.). In twenty-four hours it has risen to 2.25 per cent. After two days of treatment the osmotic pressure of the treated leaves again equals that of the untreated. In two and a half days it $\mathrm{K} \mathrm{k} 2$ 
has risen $\mathrm{I}_{5} 5$ per cent. above the control (to 4.5 per cent. $\mathrm{KNO}_{3}$ ), in four days to 2.5 per cent. above normal, and in five days the cells cannot be plasmolysed with a io per cent. $\mathrm{KNO}_{3}$ solution. They are, therefore, in all probability dead (a very few cells remain alive).

While the reduction (and subsequent increase) in the osmotic pressure of alcohol-treated cells is quite clearly seen when the values of critical concentrations of salts are used to plot a curve, as in Fig. 4, the most convincing demonstration of the reduction in osmotic pressure of a cell resulting from treatment in alcohol is to be had by observing the immediate effect of a plasmolysing salt of a concentration slightly above the critical for untreated cells.

If Elodea leaves of average resistance to alcohol are left in 8 per cent. (I.4 M) ethyl alcohol for six or eight hours and are then plasmolysed, together with untreated leaves, by a 4 per cent. $\mathrm{KNO}_{3}$ solution, practically every protoplast in the treated leaves will be prominently plasmolysed into a sphere within two minutes, while of the control leaves only relatively few cells will be but slightly plasmolysed.

Another of the physiological changes which an alcohol-treated cell undergoes is a pronounced stimulation of protoplasmic streaming.

Stimulation of Protoplasmic Streaming. Short treatment in Io per cent. ethyl alcohol is too brief a time in which to arouse the cells to active streaming before death ensues, but in low grades of alcohol with longer treatment the increase in streaming-in rate, in number of cells exhibiting it, and in types of streaming-is very marked indeed. For example, in 3, 4 , or 5 per cent. alcohol after two or three days of treatment nearly half of the total number of cells in a leaf exhibit active streaming.

While the amount and rate of streaming is very pronounced in alcoholtreated cells, the most interesting feature of this stimulation to protoplasmic activity is the great variety of abnormal types of streaming. In an alcoholtreated cell, the chloroplasts may be arranged in a belt encircling the protoplast at its centre. There may at times be two such belts, one at each end of the cell. Especially interesting is the fact that these two belts of chloroplasts in a single cell may be revolving in opposite directions. There may also be active streaming of a few chloroplasts around a mass of quiescent chloroplasts, the latter so fixed in their position that they are not dislodged and drawn into the stream even when the streaming chloroplasts rub against them.

\section{Conclusion.}

The initial effect of ethyl alcohol on the Elodea leaf cell is a pronounced increase in protoplasmic permeability permitting an exosmosis of electrolytes which results in a lower osmotic pressure within the cell, and, consequently, in a lower critical plasmolytic concentration. These 
initial changes in the physical properties of the cell are followed by an increase in critical plasmolytic concentration, and therefore by an increase in osmotic value and at least a partial decrease in permeability, as a result of prolonged treatment in ethyl alcohol. Apparently, the first effect of alcohol on protoplasm is a dilution, a dispersal of the colloidal particles of the membrane. There at least takes place some kind of destruction, a breaking down of the membrane structure, which results in increased permeability, and consequent exosmosis of dissolved substances in the cells.

These results agree well with those of Stiles and Jørgenson (23, p. 427) who found that ethyl alcohol renders the plasma membrane of potato more permeable to the solutes dissolved in the cell sap, causing a pronounced reduction in osmotic value. These workers observed a slight initial rise in osmotic pressure of the cell, which apparently takes place before the alcohol has had time to alter the membrane. The brief initial increase in osmotic value is observed only in relatively dilute alcohol solutions. Stiles and Jørgenson did not, however, observe a rise in osmotic value after prolonged treatment in alcohol, as was so marked in these experiments on Elodea.

The subsequent rise in osmotic pressure of the cell after twentyfour hours of treatment in 3 per cent. alcohol (determined by an increase in critical plasmolytic concentration) is interpreted as meaning a decrease in permeability. That there has been at least some reduction in permeability from the porous condition of the membrane attained after eighteen hours of treatment is probable, otherwise the high osmotic value subsequently reached could not be maintained, but that there has been a further decrease in permeability beyond that of the normal, and comparable with the pronounced rise in osmotic pressure, is not conclusive. The pronounced increase in osmotic value following the initial decrease due to treatment in alcohol may not be the result of permeability change at all, but of death processes.

The ultimate effect of alcohol on the protoplasm of Elodea is coagulation. Death, which results from long treatment in alcohol, is undoubtedly due to coagulation, as is evident from the fact that the unplasmolysable protoplast is often contracted, i. e. it is slightly shrunken away from the cell wall; that the surface of this shrunken mass is rough; and that the dead protoplasm is coarsely granular in appearance, i.e. it is a coagulum. The reversal of the initial effect of alcohol is probably due to secondary reactions which take place within the cell as a consequent of the initial toxic influence of the reagent. 


\title{
PART II.
}

\section{THE REACTION OF PROTOPLASM TO THE GLUCOSIDES, SAPONIN, SMILACIN, AND SENEGIN.}

\author{
EXPERIMENTAL DATA.
}

Lethal Effect of the Glucosides. What has been said of alcohol could almost be repeated to describe the effect of saponin on protoplasm. The rate at which the cells are killed, the rapid decrease in osmotic value of the cell contents as a consequent of increased permeability, and the marked stimulation to streaming, are all equally pronounced in cells treated in saponin as in those treated in alcohol.

If leaves of Elodea are placed in a one per cent. solution of saponin, smilacin, or senegin, very few of the cells will be killed in two days by saponin, half will succumb from the effects of smilacin, and more than three-fourths will be killed by senegin. These values are averages. Some cells will resist the toxic effect of a one per cent. solution of saponin for six days (of a half per cent. solution for ten days), and of a one per cent. smilacin solution for three days. Senegin is much more toxic. A one per cent. solution of this glucoside will, in twenty-four hours, cause harmful effects which are observable to the unaided eye in the discoloration of the leaves.

Changes in Permeability. If the critical concentrations of a plasmolysing salt are periodically determined for cells which have remained in a one per cent. solution of saponin for from one-half to six days, the values will gradually fall below the normal for two or three days, the time depending on the resistance of the cells to saponin, and then rise to the normal and beyond it. The average reduction in critical concentration of salt is 0.5 to 0.75 per cent. The greatest reduction obtained was one per cent. after sixty-six hours of treatment (control 3.5 per cent. of $\mathrm{KNO}_{3}$, treated 2.5 per cent.). After seventy-two hours' treatment the critical plasmolytic concentration of treated cells may be double that of the normal, namely 6 per cent. It is evident, therefore, that the curve in Fig. 4, based on data obtained from alcohol-treated cells, would, with slight modification, serve to demonstrate the change in critical plasmolytic concentration (and therefore of osmotic pressure) of saponin-treated cells.

As stated in the case of alcohol-treated cells, the most convincing demonstration of the reduction in critical plasmolytic concentration and osmotic value of the treated protoplast is to be had by observing the immediate effect on untreated and treated leaves of a plasmolysing salt of a concentration slightly above the critical value for normal cells. If this is done in the control leaf some few cells will be slightly plasmolysed 


\section{Protoplasm to some Reagents.}

in a few minutes, while in saponin-treated material nearly every cell in the leaf will be prominently plasmolysed.

The change in critical concentration of salt just described for saponin material also takes place in smilacin and senegin treated cells, with the difference that the reduction in osmotic value of the cells is more rapid in senegin than in saponin. ${ }^{1}$

Throughout this work a decrease in the critical concentration of the plasmolysing salt is interpreted to mean that there has been a reduction in osmotic pressure of the cell contents due to an increase in permeability; that is, that during treatment there has been an increase in permeability of the plasma membrane which has permitted an exosmosis of dissolved substances from the cell resulting in a lower osmotic value; consequently, a salt solution which is isosmotic with the contents of the treated cell will be of lower concentration than the salt solution which is isosmotic with the untreated cell.

There are two criticisms which can be directed against the above point of view. First, a change in osmotic value of the cell contents is not in itself alone conclusive evidence of a change in permeability. Variations in the osmotic pressure of a cell might well occur as a result of chemical change within the cell without any alteration in the permeability of the plasma membrane. The synthesis of sugar from the organic acids, or of cane sugar from two molecules of glucose, or the formation of insoluble starch from cane sugar, would greatly lower the osmotic value of the cell without any change in permeability. The toxic substance itself (alcohol or saponin) might, and probably does, break down large indiffusible molecules into smaller diffusible ones, permitting exosmosis of them without any change in permeability. Second, a reduction in critical plasmolytic concentration may mean a decrease in permeability as a result of treatment. This opinion is held by some workers, the assumption being that a reduction in critical plasmolytic concentration implies that, because of decreased permeability, the plasmolysing salt can less readily enter the cell, and will, therefore, very slowly raise the concentration (osmotic value) of the cell interior up to that of the external salt : consequently, a lower concentration of salt will plasmolyse the treated cell than will plasmolyse the normal cell. Conversely, an increase in critical plasmolytic concentration may mean that there has been an increase in permeability, since then the external salt solution can more readily enter the cell and raise its osmotic value, therefore a higher concentration of salt is needed to plasmolyse the treated cell.

If the above interpretation is correct it would explain the apparent discrepancies between the results of Osterhout $\left(17, \mathrm{p} .3^{\mathrm{I}} 8\right)$ and those of the

1 The critical concentration of smilacin-treated cells is determined with difficulty owing to the rapid collapse of the slightly plasmolysed cells. (This phenomenon will be considered later.) 
writer (21) with $\mathrm{SrCl}_{2}$. The writer has found that $\mathrm{SrCl}_{2}$ causes an increase in permeability and not, as Osterhout maintains, a decrease. This conclusion is based on the assumption that a lower critical concentration of plasmolysing salt indicates increased permeability. It becomes important, therefore, to ascertain conclusively whether or not there has been an increase, as the writer believes, or a decrease in permeability of the protoplasmic membrane when the critical plasmolysing concentration is lower as a result of treatment. This was accomplished for smilacin-treated cells by the following experiment.

If, as a result of treatment, there has been no alteration in the permeability of the plasma membrane, then smilacin-treated cells should prove to be no more sensitive to alcohol than normal cells. If permeability has decreased, then the treated cells should actually be less susceptible to the toxic effect of alcohol. If, however, permeability has been increased by treatment in smilacin, as the writer believes a decrease in critical plasmolysing concentration indicates, then the treated cells should be more susceptible to alcohol than untreated ones, since the increased permeability of the treated cells will permit a more ready entrance of the alcohol.

Leaves which had been in a 0.5 per cent. solution of smilacin for eighteen hours were treated with Io per cent. $\mathrm{KNO}_{3}$ to ascertain the number of cells killed by the glucoside. The average number of dead cells was but 0.8 per cent. of the total. Other leaves which had undergone the same treatment in smilacin for eighteen hours were, together with some control leaves, put in Io per cent. alcohol for ten minutes. By referring to the curve in Fig. 2 it will be seen that ten minutes in Io per cent. alcohol is not sufficient time to kill any cell in a normal leaf. This was true of the control leaves above mentioned. The cells of the smilacin-treated leaves, however, succumbed to the extent of $9^{2}$ per cent. as the result of a ten-minute treatment in alcohol. A similar experiment was performed, keeping the saponin-treated and the untreated leaves in 10 per cent. alcohol for twenty minutes. Seventeen per cent. of the cells were killed by alcohol in the control leaves. In the smilacin-treated leaves 95 per cent. of the cells were killed by the alcohol. The evidence seems conclusive that the plasma membrane is a more open one (since it is more permeable to alcohol) in smilacin-treated leaves than in normal leaves.

Further proof of a more permeable membrane as the direct effect of these glucosides on the plant cell is to be had from another observation. It was frequently observed that the chloroplasts of smilacin-treated cells suddenly scattered, just as if a miniature explosion had taken place within the cell, after the addition of potassium nitrate and before plasmolysis occurred. This is due undoubtedly to the effect of the salt which rapidly enters the smilacin-treated cell through its more permeable membrane.

Another phenomenon which adds further proof in support of the fact 
that a greatly increased permeability of the plasma membrane results from treatment in the saponins, is the sudden collapse of smilacin-treated cells after slight plasmolysis has taken place following the application of the plasmolysing salt.

In attempting to obtain the critical plasmolytic concentration of cells treated in 0.5 per cent. smilacin, the immediate plasmolysis of many cells is often recorded, but on observing the leaves at the expiration of the half-hour period no plasmolysed cells are to be seen. Their collapse, i. e. a sudden return of the plasmolysed protoplast to its original size, was subsequently observed. The resulting protoplast was a much disorganized one. This collapse was less often observed in saponin and senegin treated cells, but was the rule in smilacin-treated cells.

Of fifteen smilacin-treated cells observed (after twenty-one hours in a 0.5 per cent. solution) all plasmolysed to a moderate degree after four minutes in 4 per cent. $\mathrm{KNO}_{3}$. Then one plasmolysed protoplast suddenly collapsed. In five minutes five out of the fifteen protoplasts had collapsed. In nine minutes all had collapsed. This can only be interpreted to mean that the salt had entered at an abnormally rapid rate through a very porous membrane, and caused complete disorganization.

A fact worthy of note in connexion with this sudden collapse of smilacintreated cells is that the collapse was only obtained with a low percentage of salt, slightly above the critical concentration, and never with a high percentage of salt. One might expect a more abundant entrance of ions through the open membrane from a 10 per cent. $\mathrm{KNO}_{3}$, solution than from a 4 per cent. solution, yet this was not true. Smilacin-treated cells plasmolysed with 10 per cent. $\mathrm{KNO}_{3}$ never collapsed. The explanation is clear. The 4 per cent. salt entered freely without causing any change in the very permeable membrane. The 10 per cent. salt, on the other hand, coagulated the dilute membrane, thus instantly decreasing its permeability and preventing the subsequent entrance of the salt.

The great readiness with which alcohol and potassium nitrate enter the protoplast of smilacin-treated cells is evidence of a much more permeable membrane in these cells, thus substantiating the interpretation that a decrease in critical plasmolytic concentration means an increase in permeability.

That saponin markedly increases the permeability of a protoplast is also the belief of Boas (3), who arrives at this conclusion from experiments of an entirely different nature than those of the writer. Boas subjected oats to a 5 per cent. solution of saponin for twenty minutes, then placed them in 25 per cent. cane sugar and measured the amount of carbon dioxide formed. In two hours the saponin-treated material had produced three times the amount of carbon dioxide that the control material had, and in six hours' time twice as much. The increase in fermentation of the sugar is a result of increased permeability of the cells. 
The term plasma membrane is here employed to mean that part of the cell which is concerned in the phenomena of permeability without necessarily implying that all permeability phenomena are traceable to the activities of a morphologically definite membrane on the surface of protoplasm. That the surface layer of the protoplast is not the only region which is concerned in permeability changes is evident from the following observed phenomenon.

The layer of protoplasm lining the wall of a normal Elodea cell is relatively thin. In saponin-treated cells this protoplasmic layer may become increased to five times its normal thickness through excessive imbibition of water due to highly increased permeability of the protoplast as a whole. ${ }^{1}$

Protoplasmic Streaming. Streaming of protoplasm is greatly stimulated by the saponins. The number of cells exhibiting streaming, the rate, and the abnormal types are exceedingly great. ${ }^{2}$

\section{Discussion.}

The similarity in the reaction of protoplasm to two such widely differing substances as alcohol and saponin is most striking. It will be of interest to consider how far existing theories of permeability go towards explaining the effect of alcohol and saponin on protoplasm.

Overton (19), in his classical work on the osmotic properties of the cell, found that those alcohols which are most toxic to the living cell are also the alcohols which most readily attack lipoids. He therefore concluded that the chief constituents of the plasma membrane were lipoids. This lipoid theory of Overton was widely accepted at the time (I90I) and prevailed until Traube (24) twelve years later advanced the hypothesis that a substance entered a cell in proportion to its capacity to lower surface tension ; and the more rapidly it entered, the more toxic was its influence. Consequently, 'isocapillary' solutions of different narcotics produce the same end result because the same quantity enters in the same length of time.

Following Traube's surface-tension conceptions came the theory of Czapek (6). According to Czapek, water-soluble and surface-tension active substances begin to effect exosmosis of the contents of plant cells when of a concentration with the tension value of 0.685 , which Czapek believed to

1 One may here refer briefly to the bearing of this excessive imbibition of the protoplast as a whole on the structure of protoplasm. Some workers are in the habit of emphasizing the 'liquid nature' of protoplasm, and of regarding the living substance as miscible in water, apparently, therefore, assuming that the living colloid is an enulsion of protoplasm in water rather than one of water in protoplasm. Such excessive imbibition as above described could have been manifested only by a colloidal jelly. It is further of interest to note that this highly swollen protoplasmic jelly continues active streaming.

2 A more detailed description of the effect of the saponins and of other toxic substances on protoplasmic streaming is given in an article recently published $(20)$, to which the reader is referred. 
be the surface-tension value of protoplasm based on a value of I for water against air. Czapek came to this conclusion because many of the substances with which he treated cells first began to noticeably affect the osmotic properties of the membrane when they were of such a concentration as to have a surface-tension value of about 0.685 (against air). $\mathrm{He}$ concluded, therefore, that the tension value of protoplasm must be 0.685 , and that to enter the plasma membrane a reagent must be of a lower surface tension.

All of these theories have been discarded by Warburg (26), who has shown that the degree of toxicity of the methyl, ethyl, propyl, butyl, amyl alcohol series is much more closely proportional to the adsorptive powers of these alcohols than either to their lipoid solubility or their surface-tension values (capillary constants). Warburg arrived at this deduction in the following manner:

If red blood corpuscles (of bird) are frozen the thin cell membrane is burst. On thawing, a liquid mass is obtained in which the 'solid ' ${ }^{1}$ cell constituents float freely. If this liquid is centrifugalized two layers are obtained: an upper, clear, granule-free one, and a lower, cloudy layer containing the 'solid' cell particles. If one measures the respiration of the two layers separately one finds that only the lower layer respires. From this Warburg concludes that respiration depends upon the solid constituents of the cell (26, p. I 35$)$.

Warburg next studied the oxidation of inanimate substances, noticing the effect which narcotics have on their 'respiration'.

Freundlich $(8$, p. 163$)$ has shown that if an aqueous solution of oxalic acid is shaken with blood carbon, there takes place a rapid decrease in concentration of the oxalic acid due to adsorption of the acid by the carbon. Warburg sought for a possible chemical reaction, and found that oxidation of the oxalic acid into carbon dioxide and water takes place. This oxidation process can be retarded by narcotics just as can cell respiration.

In a similar manner, if an aqueous solution of cystin-the sulphur containing amino-acid of egg albumin-is added to carbon and aerated, the amino-acid is oxidized into $\mathrm{CO}_{2}, \mathrm{NH}_{3}$, and $\mathrm{H}_{2} \mathrm{SO}_{4}$. The same end products are produced as in the case of the oxidation of albumin in living cells. This oxidation can also be retarded by narcotics.

The retardation of these inanimate oxidation processes by narcotics rises with the adsorption constants of the narcotics used (methyl-, ethyl-, propyl-, and phenylurethane). For example, methylurethane, which is at the bottom of the scale with a low adsorption constant, must be of a concentration of $0.5 \mathrm{~mol}$. per litre to produce a 34 per cent. retardation of oxidation of the oxalic acid, while phenylurethane with a high adsorption con-

1 The 'solid' cell constituents to which Warburg refers are the stromata of the blood corpuscles, not solid particles of colloidal size. 
stant requires a concentration "of but $0.005 \mathrm{~mol}$. per litre to cause the same (34 per cent.) retardation in oxidation. This same relationship holds in the retardation of oxidation in living cells; thus, a 10 mols. per litre solution of methylurethane is necessary to cause a 60 per cent. retardation in respiration in red blood corpuscles, while but a $0.05 \mathrm{~mol}$. per litre solution of phenylurethane is necessary to lower respiration the same amount.

The retardation of oxidation is looked upon as a consequent of a diminution of the free adsorptive surface of the carbon (or of the living solid particles) due to the adsorption of the narcotic. That is, since oxidation is augmented by an increase in adsorptive surface, just as are many other chemical reactions (e g. gas reactions are accelerated by the presence of quartz, porcelain, carbon, \&c.), then a decrease in this surface by the adsorption of another substance, the narcotic, would cause a decrease in oxidation.

From the above experimental observations by Warburg, one can conclude that narcosis is an adsorption phenomenon; that the toxic effect of a narcotic is proportionate to its adsorption index; and that the chemical nature of the adsorptive substance (e. g. whether lipoid or protein) is not a factor in narcosis.

To consider the newest of these several theories first, it would seem clear that while Warburg's theory of narcosis is a most convincing one, and stands as the best explanation which we have of narcosis-in so far as narcosis consists in a suppression of respiration - it cannot be accepted as a theory which covers all permeability phenomena. It stands as a simple and attractive explanation of a very complex vital process, but whether the whole story is told is another matter. It is a debatable question whether the striking increase in permeability produced by such different substances as alcohol and saponin (and strontium and $\operatorname{copper}^{1}$ ) is in each case the outcome of the same single simple physical phenomenon.

The Overton lipoid theory of protoplasmic permeability is well supported by the reaction of protoplasm to the saponins, and possibly also by the toxic effect of alcohol. How far lipoids play a part in the toxicity of alcohol on protoplasm it is difficult to say. Lecithin is easily soluble in concentrated alcohol (12, pp. $\left.{ }^{5} 53-4\right)$, but cholesterin is practically insoluble in cold aqueous solutions of alcohol (2, p. 107 I). One would, therefore, not expect so low a concentration of alcohol as 10 per cent., which is highly toxic, and still less would one expect a 2 per cent. concentration, which we have seen is sufficiently concentrated to produce pronounced changes in permeability, to strongly attack the lipoid constituents of the plasma membrane. However, it is conceivable that higher concentrations of the alcohol could be arrived at as a result of adsorption on the membrane surface, a process which probably takes place. The concentration of alcohol

\footnotetext{
1 For the results on strontium and copper see (21).
} 
on the protoplasmic surface would then in time, even in a 2 per cent. solution, be sufficiently high to react with the lipoids. But, after all, there is no sound reason for believing lipoids to be the sole constituents of the plasma membrane. If we accept Nathansohn's (14) mosaic conception of membrane constitution - and it seems to me that we must-then we are forced to grant the likelihood of alcohol attacking proteins and other possible constituents of the cell membrane.

Saponins of low concentration attack (emulsify) lipoids. That lipoids are a part of the chemical make-up of the plasma membrane is generally accepted. MacDougal (11), without emphasizing the presence of any one single substance in the plasmatic membrane, regards lecithin as an important constituent. Other workers, Boas (4), Kahho (10), et al., have been led by their experimental results to the belief that lipoids are one of the chief constituents of the plasma membrane. Bayliss (1, p. I30) regards certain permeability and other phenomena as attributable to the presence of a lipoid peripheral layer.

It is unwise, in the present limited state of our knowledge of the chemical constitution of protoplasm, to give undue emphasis to any one single substance in the membrane, yet that lipoids are one of the possible components of the protoplasmic surface layer seems likely. Whether they occur as free fat or, more likely, in chemical union with proteins (15), we do not fully know. Whatever the actual chemical make-up of the membrane is, the experimental data here given stands in opposition to the assumption of Grafe $(9$, p. 29), that a knowledge of 'the purely chemical constitution of the cell constituents has not given any explanation of the entrance and exit of different substances'.

The Overton lipoid theory must still stand as one of the possible factors concerned in permeability phenomena.

It is reasonably clear that both alcohol and saponin increase permeability in the Elodea cell. Such an increase in permeability means a more dispersed membrane, and therefore a lower surface tension. Conversely, a reduction in the surface tension of protoplasm will mean increased permeability. There is, consequently, good reason to regard surface tension forces as playing a part in changes in permeability. It seems likely, therefore, that the surface-tension ideas of Traube and Czapek may not be as fallacious as some have implied. That a reduction in surface tension actually does take place in the treated cells is confirmed by the following observations :

Untreated Elodea leaf cells mostly plasmolyse with concave surfaces, which are often very deeply concave, indicating a high surface-tension value of the plasma membrane of the normal cell. The treated cell (half an hour in 10 per cent. alcohol), on the other hand, plasmolyses, nine times out of ten, with a convex surface, even when the plasmolysis is ever so slight, 
indicating lower surface tension, since the membrane readily loses its hold on the cell wall.

A still more beautiful demonstration of a reduction in surface tension is to be had from the absence in alcohol-treated cells of those delicate protoplasmic strands which radiate from a plasmolysed protoplast to the cell wall in an untreated Elodea cell $(5$, p. 18). These long fine protoplasmic threads could only be formed by a protoplasmic surface of high tension value

Czapek maintained that a substance must have a tension value less than $0.685^{-}$-which he thought to be the surface-tension value of protoplasm (water being $\mathrm{I}$ ) -in order to affect the diosmotic properties of protoplasm. Czapek based this theory on the idea that, since a lower tension value means greater surface activity, then an entering substance must possess greater surface activity, consequently a lower surface tension, than the constituents of the plasma membrane in order to pass through the membrane. It will be interesting to see how the surface-tension values of the saponins and the alcohols used compare with the critical value given by Czapek.

The surface-tension value of I per cent. ethyl alcohol is 0.933 , of 8 per cent. alcohol it is 0.720 , of 9 per cent. 0.700 , and of 10 per cent. $0.682 .{ }^{1}$ The surface-tension value of I per cent. saponin is 0.885 , of I per cent. senegin 0.819 , and of $I$ per cent. smilacin $0.68 \mathrm{I} .^{2}$ It will be seen that while none of the surface-tension values of the three glucosides, with one exception, that of smilacin, are near the critical toxic value of 0.685 set by Czapek, yet the tension values of the glucosides and of all the more prominently toxic concentrations of alcohol are considerably less than $\mathrm{I}$.

It is of interest to note that 9 per cent. ethyl alcohol, which we found to be a critical concentration in the toxicity of this alcohol for protoplasmsince above this percentage cells are killed in relatively few minutes, while below it many hours are necessary to kill-has a tension value of very nearly the critical value set by Czapek.

We have seen, however, that a much lower percentage of ethyl alcohol than 9 is sufficient to effect osmosis of the cell contents. As low as a 3 per cent., even a I per cent., solution will, in several days, materially affect the diosmotic properties of the cell. We can only explain the effect of the low percentage of alcohol, on the basis of Czapek's theory, by assuming that there is a concentration of the alcohol at the surface of the protoplast. In time the alcohol thus concentrated on the plasma membrane will be of sufficient strength to have a surface-tension value low enough to cause a reduction in the tension of the protoplasmic surface, and consequently increase the permeability of the membrane. While such an assumption is

1 These values are taken from Duclaux (6, pp. 22-3).

2 These values were obtained by comparing the number of drops of water with the number of drops of reagent, of the same volume and temperature, from a Traube stalagmometer. The value of water is taken as unity. 
possible, yet, without experimental data to support it, it seems preferable to regard the critical toxic tension value set by Czapek as one not proven to exist in the sense which Czapek intended it.

The theory of Czapek was early criticized by Vernon (25), and later received drastic criticism at the hands of Stiles and Jørgensen (22). These workers repeated the experiments of Czapek, employing the electrical conductivity method of Kohlrausch for determining the exosmosis of electrolytes. As a result of their experiments they conclude that, "not only is the theory founded by Czapek upon his experimental results untenable, but ... the facts on which he bases his theory are merely illustrations of experimentation due partly to the crudity of the method employed, and partly to a selection and arbitrary arrangement of experiments ' $(22$, p. 50$)$.

That Czapek's theory is not universally applicable is true. One need merely consider the 'oligodynamic' (9) action of copper water (the term is Nägeli's, and refers to the extremely high toxicity of water in which there is a slight trace of copper). The action of copper water (water in which several copper coins had remained overnight) on Elodea leaves was found by the writer (21), in its effect on permeability and protoplasmic streaming, to be similar to and as pronounced as that of saponin. The same is true of a weak (I per cent.) solution of strontium chloride. Yet both of these highly toxic solutions possess a surface-tension value which differs exceedingly little from that of pure water.

Czapek himself found that some reagents do not fit in with his theory, and he assumed in these cases that a 'special toxic action' takes place. Such an assumption is destructive to his theory in so far as its universal applicability is concerned. However, in reply to Vernon, Czapek made one statement which stands in substantial support of his hypothesis. He (7, p. III) stated that his theory must collapse only when there has been found one substance which in spite of a surface-tension value below 0.685 is not deadly.

Czapek's theory fails utterly as a complete explanation of all permeability changes due to the poisonous action of toxic substances. But the entire sweeping aside of the theory is not, in my opinion, justifiable; that is, we cannot completely ignore the possibility of alterations in surface tension being a factor, and possibly a very prominent factor, in permeability changes.

It is most remarkable that substances which differ chemically so widely as do ethyl alcohol and saponin (and strontium chloride and copper oxide) should all cause the same pronounced change in the physiological condition of protoplasm. One hesitates to believe that any one theory will explain the reaction of protoplasm to all these reagents even though the end result, an increase in permeability and a stimulation to streaming, is the same in each case. 
It seems that there are two criticisms which can be directed against all theories of protoplasmic permeability so far advanced: first, their authors have attempted to explain a complex vital phenomenon on the basis of a single physical process ; and second, results obtained on one type of tissue are allowed to form the foundation of a theory intended to cover all living systems.

\section{SUMMARY.}

I. Ethyl alcohol of a concentration of Io per cent. will kill the cells in the average leaf of Elodea at the following rate: O.I per cent. of the total number are killed in 15 minutes, I per cent. in 20 minutes, 60 per cent. in 30 minutes, 80 per cent. in I hour, 95 per cent. in 2 hours.

2. The average cell of the leaf of Elodea is killed in the following concentrations of ethyl alcohol in the following respective lengths of time: 10 per cent. alcohol in 28 minutes, 9 per cent. in 2 hours, 8 per cent. in I 2 hours, 7 per cent. in 18 hours, 6 per cent. in 26 hours, 5 per cent. in 40 hours, 4 per cent. in 3 days, 3 per cent. in 5 days, 2 per cent. in Io days.

3. Short treatment of the Elodea leaf cell in ethyl alcohol results in a reduction of osmotic pressure within the cell due, apparently, to an increase in permeability and consequent exosmosis of the cell contents. With longer treatment the osmotic value of the cell rises until it far surpasses the value of the untreated cell.

4. Treatment in ethyl alcohol causes a pronounced stimulation to streaming in the Elodea leaf cell.

5. The permeability of the Elodea leaf cell is increased and the osmotic value, therefore, decreased by brief treatment in a I per cent. solution of the glucosides, saponin, smilacin, and senegin. Longer treatment results in an increase of osmotic pressure.

6. A change in the critical plasmolytic concentration of the salt employed for determining the osmotic pressure of a cell may mean either an increase or a decrease in permeability depending upon the interpretation. It was possible to show by several different observations that a lower critical plasmolytic concentration means increased permeability in the case of saponin-treated cells.

7. The saponins greatly stimulate the streaming of protoplasm.

8. The theories of Overton, Traube, Czapek, and Warburg, bearing on permeability and narcosis, are considered, and it is shown that each theory is supported by experimental evidence, but none of them are alone sufficient as a complete explanation of all permeability phenomena.

The experimental work on which this article is based was carried out in the laboratories of the Botanical Institute of the University of Geneva, Switzerland, where I enjoyed the privileges of a guest through the courtesy 
of Professor R. Chodat. I wish to express to Professor Chodat my appreciation of his kindness in placing the facilities of the Institute at my disposal and of his helpful assistance during the progress of the work. To Professor W. Stiles, of Reading, England, I am also indebted for valued criticism of the manuscript of this article.

\section{BIBLIOGRAPHY.}

1. Bayliss, W. M. : Principles of General Physiology. London, I9I 5.

2. Beilstein, F.: Handbuch der Organischen Chemie, II. Hamburg, i 896.

3. BoAs, F. : Beiträge zur Kenntnis der Wirkung des Saponins auf die pflanzliche Zelle. Ber. der deut. Bot. Gesell., xxxviii. 350-3, I 92 I.

4. - Untersuchungen über die Mitwirkung der Lipoide beim Stoffaustausch der pflanzlichen Zelle. Biochem. Zeitsch., cxvii. I66-214, I921.

5. Chodat, R.: Principes de Botanique. Geneva, 1920.

6. CzAPeK, E.: Über eine Methode zur direkten Bestimmung der Oberflächenspannung der Plasmahaut von Pflanzenzellen. Jena, I9ı.

7. - Weitere Beiträge zur Physiologie der Stoffaufnahme in die lebende Pflanzenzelle. I. Über die Annahme von Lipokolloiden in der Plasmahaut. Internat. Zeitsch. für physik.chem. Biologie, i. 108-23, I9I4.

8. FreUndlich, H. : Kapillarchemie. Leipzig, igri.

9. Grafe, V.: Metbodik der Permeabilitätsbestimmungen bei Pflanzenzellen. E. Abderhalden, Handbuch der biologischen Arbeitsmethoden, Abt. xi, Teil 2, Heft I. Vienna, I920.

10. Kaнно, H.: Über die Beeinflussung der Hitzekoagulation des Pflanzenprotoplasmas durch Neutralsalze. Biochem. Zeitsch., cxvii. 87-95, 1921.

11. MacDougal, D. T. : The Distentive Agencies in the Growth of the Cell. Proc. Soc. Exp. Biol. and Med., xix. го3-10, I92 I.

12. Meyer, V., and Jacobson, P. : Lehrbuch der Organischen Chemie, i. 2. Teil. Leipzig, I9I3.

13. N̈̈GELI, C. : Ueber oligodynamische Erscheinungen in lebenden Zellen. Nouveaux Mémoires de la Société Helvétique des Sciences Naturelles, xxxiii, I ${ }^{\mathrm{re}}$ livraison, I-52, I893.

14. Nathansohn, A. : Über die Regulation der Aufnahme anorganischer Salze durch die Knollen von Dahlia. Jahrb. wiss. Bot., xxxix. 605-44, 1904 .

15. Osborne, T. B., and Campbell, G. F.: The Proteids of the Egg Yolk. Journ. Amer. Chem. Soc., xxii. 413-22, 1900.

16. Osterhout,'W. J. V.: The Permeability of Living Cells to Salts in Pure and Balanced Solutions. Science, xxxiv. $187-9$, I9II.

17. $\quad$ On the Decrease of Permeability due to Certain Bivalent Kations. Bot. Gaz., lix. 3I 7-30, I9I5.

18. Overton, E. : Ueber die allgemeinen osmotischen Eigenschaften der Zelle, ihre vermutlichen Ursachen und ihıe Bedeutung für die Physiologie. Vierteljahresschrift d. Naturfor. Gesell. Zürich, xliv. 88-1 35,1899 .

19. : Studien über die Narkose. Jena, I901.

20. Seifriz, W. : A Method for inducing Protoplasmic Streaming. New Phytol., xxi. I07-I 2, 1922.

21. : Some Observations in Permeability and Antagonism. Bot. Gaz., lxxv, Oct., I923.

22. Stiles, W., and Jørgensen, I.: Studies in Permeability. IV. The Action of Various

Organic Substances on the Permeability of the Plant Cell and its Bearing on Czapek's

Theory of the Plasma Membrane. Ann. Bot., xxxi. 47-76, I9I 7 .

23. — : Studies in Permeability. V. The Swelling of Plant Tissue in Water and its Relation to Temperature and Various Dissolved Substances. Ibid., 415-34, 1917.

24. Traube, J.: Theorie der Narkose. Pflüger's Arch. f. d. ges. Physiol., cliii. 276-308, I9I3.

25. Vernon, H. M.: Die Rolle der Oberflächenspannung und der Lipoide für die lebenden Zellen. Biochem. Zeitsch., li. I-25, I9I3.

26. Warburg, O. : Physikalische Chemie der Zellatmung. Ibid., exix. I34-66, I92r. 


\section{$2 \mathrm{BHL}$ Biodiversity Heritage Library}

Seifriz, William. 1923. "Observations on the reaction of protoplasm to some reagents." Annals of botany 37, 489-509.

https://doi.org/10.1093/oxfordjournals.aob.a089861.

View This Item Online: https://www.biodiversitylibrary.org/item/270686

DOI: https://doi.org/10.1093/oxfordjournals.aob.a089861

Permalink: https://www.biodiversitylibrary.org/partpdf/319098

\section{Holding Institution}

New York Botanical Garden, LuEsther T. Mertz Library

\section{Sponsored by}

BHL-SIL-FEDLINK

\section{Copyright \& Reuse}

Copyright Status: Public domain. The BHL considers that this work is no longer under copyright protection.

This document was created from content at the Biodiversity Heritage Library, the world's largest open access digital library for biodiversity literature and archives. Visit BHL at https://www.biodiversitylibrary.org. 